\title{
Description of Komagataella phaffii sp. nov. and the transfer of Pichia pseudopastoris to the methylotrophic yeast genus Komagataella
}

\author{
Cletus P. Kurtzman
}

Correspondence

Cletus P. Kurtzman

kurtzman@ncaur.usda.gov

\author{
Microbial Genomics and Bioprocessing Research Unit, National Center for Agricultural \\ Utilization Research, Agricultural Research Service, US Department of Agriculture, $1815 \mathrm{~N}$. \\ University Street, Peoria, IL 61604, USA
}

\begin{abstract}
The new methanol-assimilating yeast species Komagataella phaffii Kurtzman sp. nov. (type strain NRRL Y $-7556^{\top}=$ CBS $2612^{\top}$ ) is described. Of the four known strains of this species, two were isolated from black oak trees in California, USA, one from an Emory oak in Arizona, USA, and one from an unidentified source in Mexico. The species forms hat-shaped ascospores in deliquescent asci and appears to be homothallic. Analysis of nucleotide sequences from domains D1/D2 of large-subunit (26S) rDNA separates the new species from Komagataella pastoris, the type species of the genus, and from Pichia pseudopastoris, which is here renamed Komagataella pseudopastoris (Dlauchy, Tornai-Lehoczki, Fülöp \& Péter) Kurtzman comb. nov. (type strain NRRL Y-27603 ${ }^{\top}=$ CBS $9187^{\top}=$ NCAIM Y $01541^{\top}$ ). On the basis of D1/D2 26S rDNA sequence analysis, the three species now assigned to the genus Komagataella represent a clade that is phylogenetically isolated from other ascomycetous yeast genera.
\end{abstract}

Yeast species that assimilate methanol as a carbon source represent a relatively small proportion of known yeasts, all but one of which are ascomycetes (Kurtzman \& Fell, 1998). When grown on methanol, the species show a marked proliferation of peroxisomes, which produce methanol oxidase and dihydroxyacetone synthetase, as well as several other enzymes, and the peroxisomes may then account for $80 \%$ of the volume of the cell (Harder \& Brooke, 1990; Veenhuis et al., 1983). Because of this large accumulation of enzymes, initial interest in the methanol yeasts was for production of single-cell protein. Later, it was recognized that the species could serve as hosts for heterologous gene expression. One of these species, Pichia pastoris, has been extensively developed for production of biotechnologically important proteins, and the technology is available for both experimental and commercial uses (Cregg et al., 1985, 1993; Sreekrishna \& Kropp, 1996).

Yamada et al. (1995) noted from comparisons of partial sequences of $18 \mathrm{~S}$ and $26 \mathrm{~S}$ rRNAs that there were considerable differences between $P$. pastoris and other methanolassimilating yeasts and, on the basis of these differences, proposed the genus Komagataella for classification of $P$. pastoris. This proposal was not accepted by Kurtzman (1998) because of the small number of species included in the original comparison and the absence of strong statistical support for branches in the phylogenetic trees that were

Published online ahead of print on 12 November 2004 as DOI 10.1099/ijs.0.63491-0. presented. Kurtzman \& Robnett (1998) compared all known ascomycetous yeasts from partial sequences of $26 \mathrm{~S}$ rDNA and found that $P$. pastoris and a closely related new species were well separated from other yeasts, including those methanol-assimilating species that form a clade with Pichia angusta (Hansenula polymorpha). More recently, Dlauchy et al. (2003) described Pichia pseudopastoris, a species closely related to $P$. pastoris and the undescribed new species noted above. With the discovery of two additional species, it has become clear that the P. pastoris clade is well isolated from other known yeasts and that Komagataella is a phylogenetically distinct genus. In the present study, a new methanol-assimilating yeast is described and placed in the genus Komagataella, and the recently described $P$. pseudopastoris is transferred to this genus as a new combination.

Strains of the proposed new species and their sources of isolation are given in Table 1. The strains are maintained in the Agricultural Research Service Culture Collection (NRRL), National Center for Agricultural Utilization Research, Peoria, IL, USA. The composition of culture media used in this study, as well as the methods for preparing and assessing fermentation and assimilation tests, were given by Yarrow (1998).

Methods for DNA isolation and sequencing of domains D1/D2 of large-subunit rDNA were previously given (Kurtzman \& Robnett, 1998). Both strands of the DNAs compared were sequenced with the ABI BigDye Terminator Cycle Sequencing kit (Applied Biosystems) using either an 
Table 1. Strains of Komagataella phaffii compared

NRRL, ARS Culture Collection, National Center for Agricultural Utilization Research, Peoria, IL, USA; CBS, Centraalbureau voor Schimmelcultures, Utrecht, The Netherlands. Strain K-239 (=NRRL YB-4290) was obtained from the Herman J. Phaff Culture Collection, University of California, Davis, CA, USA; strain SUB 85-263.1 was obtained from W. T. Starmer, Syracuse University, Syracuse, NY, USA.

\begin{tabular}{|ll|}
\hline Strain & \multicolumn{1}{c|}{ Source of isolation } \\
\hline NRRL Y- $7556^{\mathrm{T}}\left(=\mathrm{CBS} 2612^{\mathrm{T}}=\mathrm{K}-239^{\mathrm{T}}\right)$ & Black oak (Quercus kelloggii), CA, USA \\
NRRL Y-12729 & Unidentified substrate, Mexico \\
NRRL Y-17741 $(=$ SUB $85-263.1)$ & Sap flux, Emory oak (Quercus emoryi), near Tucson, AZ, USA \\
NRRL YB-4289 & Black oak, CA, USA \\
\hline
\end{tabular}

ABI 3100 or an ABI 3730 automated DNA sequencer according to the manufacturer's instructions. Following visual alignment of sequences, estimates of phylogenetic relatedness among species were determined using the maximum-parsimony and neighbour-joining programs of PAUP $^{*}$ 4.063a (Swofford, 1998). Bootstrap support for phylogenetic trees was determined from 1000 replications.

Phylogenetic analysis of domains D1/D2 of large-subunit (26S) rDNA nucleotide sequences placed the proposed new species in a clade with Komagataella (Pichia) pastoris and Pichia pseudopastoris (Fig. 1). The clade has $100 \%$ bootstrap support. The four strains of the proposed new species examined in this study have identical D1/D2 nucleotide sequences. The sequence for NRRL Y $-7556^{\mathrm{T}}$ was reported in an earlier study (Kurtzman \& Robnett, 1998) and found in this study to have one erroneous nucleotide determination, which has been corrected in GenBank. The new species differs from $K$. pastoris at 10 positions (6 substitutions, 4 indels) and from $P$. pseudopastoris at 14 positions (6 substitutions, 8 indels). Each of these species shows greater than $1 \%$ substitutions with its nearest neighbour, providing the genetic basis for predicting that each taxon is a separate species, which is based on earlier findings that strains showing $1 \%$ or greater non-contiguous substitutions represent separate species (Kurtzman \& Robnett, 1998). Presently, the only well-documented exception to this prediction is among interfertile strains of Clavispora lusitaniae, which are unusually polymorphic in the D1/D2 domain (Lachance et al., 2003).

\section{Latin diagnosis of Komagataella phaffii Kurtzman sp. nov.}

In agaro malti post dies 3 ad $25^{\circ} \mathrm{C}$, cellulae vegetativae globosae $(2 \cdot 3-7 \cdot 0 \mu \mathrm{m})$ aut ovoidae $(1 \cdot 8-3 \cdot 0 \times 3 \cdot 3-6 \cdot 2 \mu \mathrm{m})$, singulae vel binae. In agaro morphologico post dies 7 ad $25^{\circ} \mathrm{C}$, incrementum fuscum pallidum, nitens, butyrosum; centrum coloniae sublatum; margo undulato. Pseudohyphae et hyphae verae non fiunt. Species homothallica. Asci liberi, 2-4 ascosporae petasoformes, liberi. Glucosum fermentatur. Galactosum, sucrosum, maltosum, lactosum, raffinosum et trehalosum non fermentantur. Assimilantur glucosum, trehalosum, L-rhamnosum, methanolum, ethanolum, glycerolum, D-mannitolum, D-glucitolum, DL-acidum lacticum, acidum succinicum, acidum citricum (variabile) et cadaverinum. Non assimilantur galactosum, L-sorbosum, sucrosum, maltosum, cellobiosum, lactosum, melibiosum, raffinosum, melezitosum, inulinum, amylum solubile, D-xylosum, L-arabinosum, D-arabinosum, D-ribosum, D-glucosaminum, N-acetyl-Dglucosaminum, erythritolum, ribitolum, galactitolum, methyl $\alpha$-D-glucosidum, salicinum, D-gluconas, 2-keto-D-gluconas, 5-keto-D-gluconas, saccharatas, inositolum, hexadecanum et potassii nitras. Amylum non formatur. Vitaminae externae ad crescentiam necessaria sunt. Gelatinum non liquescit; in cycloheximidi $100 \mu \mathrm{g} \mathrm{ml}^{-1}$ crescit. Augmentum fiunt temperatura $37^{\circ} \mathrm{C}$. Species nova a speciebus aliis sequentibus nucleotiditis D1/D2 26S rDNA distinguenda. Typus: NRRL Y-7556 ${ }^{\mathrm{T}}\left(=\mathrm{CBS} 2612^{\mathrm{T}}\right)$, designat stirpem typicum. Isolata Quercus kelloggii, Californica, USA, depositata in Collectione Culturarum ARS (NRRL), Peoria, Illinois, USA.

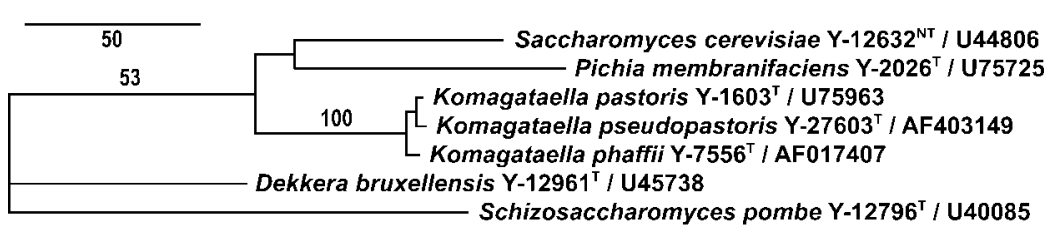

Fig. 1. Phylogenetic relationships among species of Komagataella determined from maximum-parsimony analysis of domains D1/ D2 of $26 \mathrm{~S}$ rDNA; one of five most parsimonious trees. Tree length, 464; consistency index, 0.897; retention index, 0.682; rescaled consistency index, 0.612; homoplasy index, $0 \cdot 103$. Bootstrap values are from 1000 replications; frequencies under $50 \%$ are not given. Schizosaccharomyces pombe was the outgroup species in the analysis. 


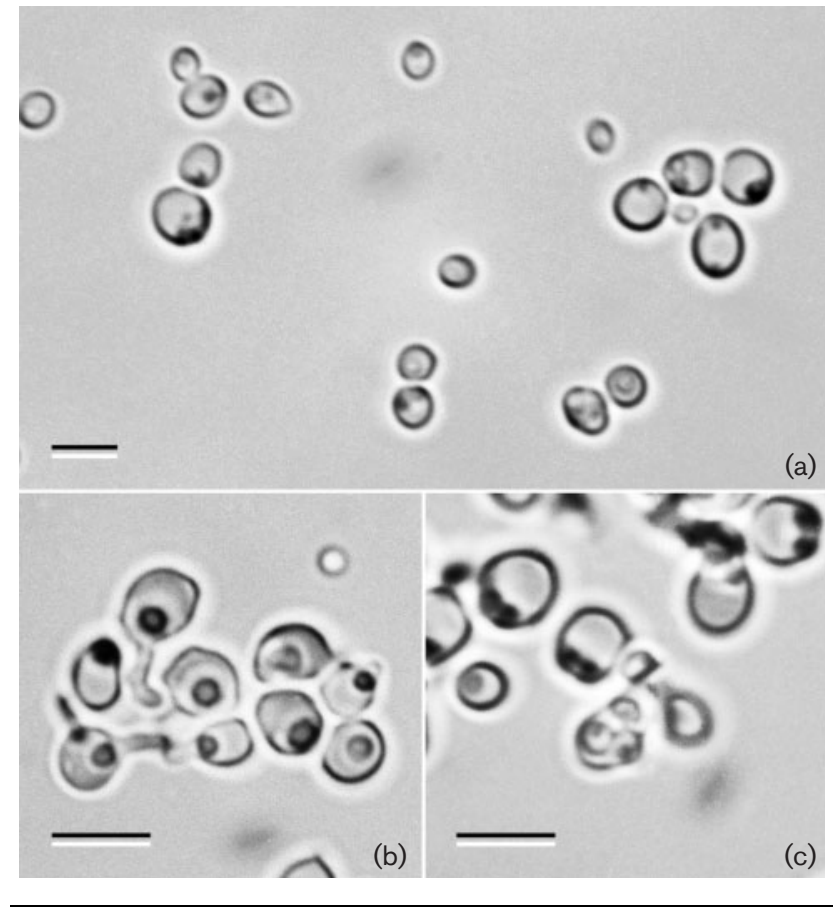

Fig. 2. Komagataella phaffii sp. nov. NRRL Y-7556 ${ }^{\top}$. Incubated at $25{ }^{\circ} \mathrm{C}$ on $5 \%$ ME agar: (a) budding cells at 3 days; (b) cells with conjugation tubes at 6 days; (c) deliquescent ascus with four hat-shaped ascospores at 6 days. Bars, $5 \mu \mathrm{m}$.

\section{Description of Komagataella phaffii Kurtzman sp. nov.}

Komagataella phaffii (phaff'i.i. N.L. gen. masc. n. phaffii referring to Herman Jan Phaff, whose ecological studies provided the type strain of this species).

After 3 days growth on $5 \%$ malt extract (ME) agar at $25^{\circ} \mathrm{C}$, cells are spherical $(2 \cdot 3-7 \cdot 0 \mu \mathrm{m})$ to ovoid $(1 \cdot 8-3 \cdot 0 \times 3 \cdot 3-$ $6 \cdot 2 \mu \mathrm{m}$ ), and occur singly and in pairs (Fig. $2 \mathrm{a}$ ). Budding is multilateral. Growth has a dull surface, is tannish-white in colour and butyrous in texture. Growth under the coverslip of a Dalmau plate culture on yeast morphology agar after 7 days at $25^{\circ} \mathrm{C}$ showed neither pseudohyphae nor true hyphae. Aerobic growth on this medium is glistening, white, butyrous and with a sparingly raised centre. Colony margins are finely to moderately lobate.

Cultures were examined for ascospore formation following incubation at 15 and $25^{\circ} \mathrm{C}$ on $5 \% \mathrm{ME}$, YM, RG and Gorodkowa agars. Ascosporulation was sparse, but most common on $5 \% \mathrm{ME}$ agar at $25^{\circ} \mathrm{C}$ after 1 week. Asci form two to four hat-shaped ascospores and become deliquescent. The asci may be unconjugated, form infrequently by conjugation of independent cells or show conjugation between a cell and its bud. Cells with conjugation tubes are not uncommon (Fig. 2b), but the frequency of conjugation between independent cells appears quite low. In view of conjugation between cells and their buds, the species appears to be homothallic.
Glucose is fermented. Galactose, sucrose, maltose, lactose, raffinose and trehalose are not fermented. Assimilation of carbon compounds is the following: glucose, +; galactose, -; L-sorbose, -; sucrose, -; maltose, -; cellobiose, -; trehalose, +; lactose, -; melibiose, -; raffinose, -; melezitose, -; inulin, -; soluble starch, -; D-xylose, -; L-arabinose, -; D-arabinose, -; D-ribose, -; L-rhamnose, +; D-glucosamine, -; $N$-acetyl-D-glucosamine, -; methanol, +; ethanol, +; glycerol, +; erythritol, -; ribitol, -; galactitol, -; D-mannitol, +; D-glucitol, +; methyl $\alpha$-D-glucoside, -; salicin, -; D-gluconate, -; 2-keto-Dgluconate, -; 5-keto-D-gluconate, -; saccharate, -; DLlactate, + ; succinate, + ; citrate, $\mathrm{v}$; inositol, - ; hexadecane, -. Assimilation of nitrogen compounds: nitrate, -; cadaverine, + . Growth or responses on other tests: vitamin-free medium, -; $10 \% \mathrm{NaCl} / 5 \%$ glucose, -; starch formation, -; gelatin liquefaction, -; $100 \mu \mathrm{g}$ cycloheximide $\mathrm{ml}^{-1},+; 37^{\circ} \mathrm{C},+$.

Source of cultures: the four known strains of this species and their sources are listed in Table 1. Type: NRRL Y-7556 ${ }^{\mathrm{T}}$ $\left(=\right.$ CBS $\left.2612^{\mathrm{T}}\right)$, isolated from black oak in California, is preserved as a lyophilized culture in the ARS Culture Collection (NRRL), Peoria, IL, USA.

Ecology: three of the four K. phaffii strains given in Table 1 are from oak trees that occur in California and Arizona. M.-A. Lachance (personal communication) determined from D1/D2 26S rDNA sequence analysis that the K. pastoris strains reported by Ganter et al. (1986) to occur in sap fluxes of Quercus emoryi (nine strains) and Populus fremontii (four), as well as on associated Drosophila brooksae (two), are instead $K$. phaffii. Consequently, tree fluxes in the Sonoran region may represent the primary habitat of $K$. phaffii.

In view of the phylogenetic circumscription of the genus Komagataella from analysis of gene sequences, Pichia pseudopastoris is transferred to this genus as a new combination.

\section{Komagataella pseudopastoris (Dlauchy, Tornai- Lehoczki, Fülöp \& Péter) Kurtzman comb. nov.}

Basionym: Pichia pseudopastoris Dlauchy, Tornai-Lehoczki, Fülöp \& Péter. Antonie van Leeuwenhoek 83 (2003), 330. Type strain: CBS $9187^{\mathrm{T}}=$ NCAIM Y $01541^{\mathrm{T}}=$ NRRL $\mathrm{Y}-27603^{\mathrm{T}}$.

The three species now assigned to Komagataella cannot be separated from one another by reactions on the standard fermentation and assimilation tests commonly used in yeast taxonomy. For this reason, the type strain of $K$. phaffii (NRRL Y-7556 ${ }^{\mathrm{T}}$ ) had been considered a member of $K$. pastoris until rDNA sequence analysis demonstrated it to be a distinct species (Kurtzman \& Robnett, 1998). Dlauchy et al. (2003) initially detected strains of K. pseudopastoris from restriction analysis of $18 \mathrm{~S}$ rDNA during an ecological study of methanol-assimilating yeasts, and verified the genetic divergence of this species from K. pastoris by analysis of domains D1/D2 of 26S rDNA. 
Dlauchy et al. (2003) reported that, of the 32 strains of $K$. pastoris examined, all grew with $0.03 \%$ tannic acid, albeit one strain slowly, whereas the four strains of $K$. pseudopastoris essentially failed to grow in the presence of tannic acid at that concentration. Discovery of this growth response has provided a phenotypic test for separation of $K$. pastoris from K. pseudopastoris. Unfortunately, an additional phenotypic test that separates $K$. phaffii from the other two Komagataella species has not been found, and it is recommended that the species be identified from their unique sequences in domains D1/D2 26S rDNA. Sequence analysis provides a definitive identification of the species and will lead to detection of any other Komagataella species not currently known. Yamada et al. (1995) described colonies of $K$. pastoris as mucoid. As a point of clarification, others (Dlauchy et al., 2003; Kurtzman, 1998) have reported colonies of the three known species to be butyrous, not mucoid.

Gene sequence comparisons have shown that the ascomycetous yeasts are a phylogenetically diverse assemblage of species that represent a large number of genera, many of which are not phylogenetically circumscribed. Recognition and acceptance of genera is often affected by the number of taxa in an analysis. The initial study describing Komagataella had relatively few species in the comparison (Yamada et al., 1995). With the inclusion of all known ascomycetous yeast species in the gene sequence analysis (Kurtzman \& Robnett, 1998), and the discovery of two new species closely related to K. pastoris, the genus Komagataella is seen to represent a phylogenetically distinct clade.

\section{Acknowledgements}

Thanks are given to Christie J. Robnett for determining rDNA sequences for the new species and to Eleanor Basehoar-Powers for conducting fermentation and assimilation tests on strains of the new taxon.

\section{References}

Cregg, J. M., Barringer, K. J., Hessler, A. Y. \& Madden, K. R. (1985). Pichia pastoris as a host system for transformations. Mol Cell Biol 5, 3376-3385.
Cregg, J. M., Vedvick, T. S. \& Raschke, W. C. (1993). Recent advances in the expression of foreign genes in Pichia pastoris. Biotechnology 11, 905-910.

Dlauchy, D., Tornai-Lehoczki, J., Fülöp, L. \& Péter, G. (2003). Pichia (Komagataella) pseudopastoris sp. nov., a new yeast species from Hungary. Antonie van Leeuwenhoek 83, 327-332.

Ganter, P. F., Starmer, W. T., Lachance, M. A. \& Phaff, H. J. (1986). Yeast communities from host plants and associated Drosophila in southern Arizona: new isolations and analysis of the relative importance of hosts and vectors on community composition. Oecologia 70, 386-392.

Harder, W. \& Brooke, A. C. (1990). Methylotrophic yeasts. In Yeast Biotechnology and Biocatalysis, pp. 395-428. Edited by H. Verachtert \& R. De Mot. New York: Marcel Dekker.

Kurtzman, C. P. (1998). Pichia E. C. Hansen emend. Kurtzman. In The Yeasts, a Taxonomic Study, 4th edn, pp. 273-352. Edited by C. P. Kurtzman \& J. W. Fell. Amsterdam: Elsevier.

Kurtzman, C. P. \& Fell, J. W. (1998). Summary of species characteristics. In The Yeasts, a Taxonomic Study, 4th edn, pp. 915-947. Edited by C. P. Kurtzman \& J. W. Fell. Amsterdam: Elsevier.

Kurtzman, C. P. \& Robnett, C. J. (1998). Identification and phylogeny of ascomycetous yeasts from analysis of nuclear large subunit (26S) ribosomal DNA partial sequences. Antonie van Leeuwenhoek 73, 331-371.

Lachance, M. A., Daniel, H. M., Meyer, W., Prasad, G. S., Gautam, S. P. \& Boundy-Mills, K. (2003). The D1/D2 domain of the largesubunit rDNA of the yeast species Clavispora lusitaniae is unusually polymorphic. FEMS Yeast Res 4, 253-258.

Sreekrishna, K. \& Kropp, K. E. (1996). Pichia pastoris. In Nonconventional Yeasts in Biotechnology, pp. 203-253. Edited by K. Wolf. Berlin: Springer.

Swofford, D. L. (1998). PAUP ${ }^{*} 4.0$ - Phylogenetic Analysis Using Parsimony. Sunderland, MA: Sinauer.

Veenhuis, M., van Dijken, J. P. \& Harder, W. (1983). The significance of peroxisomes in the metabolism of one-carbon compounds in yeasts. Adv Microb Physiol 24, 1-82.

Yamada, Y., Matsuda, M., Maeda, K. \& Mikata, K. (1995). The phylogenetic relationships of methanol-assimilating yeasts based on the partial sequences of $18 \mathrm{~S}$ and $26 \mathrm{~S}$ ribosomal RNAs: the proposal of Komagataella gen. nov. (Saccharomycetaceae). Biosci Biotechnol Biochem 59, 439-444.

Yarrow, D. (1998). Methods for the isolation, maintenance and identification of yeasts. In The Yeasts, a Taxonomic Study, 4th edn, pp. 77-100. Edited by C. P. Kurtzman \& J. W. Fell. Amsterdam: Elsevier. 